\title{
POST-RELEASE ATTACKS ON INVALID FEDERAL CONVICTIONS: OBSTACLES TO REDRESS BY CORAM NOBIS
}

THE effects of a felony conviction extend beyond the period of custody. After a prisoner has served the full term of his sentence, parole, or probation, he may be subject to civil disabilities, ${ }^{1}$ in addition to the social and economic consequences of having been a "convict." Furthermore, his conviction may even lead to additional imprisonment. Upon his release another jurisdiction may recommit him on the ground that the criminal act for which he was convicted violated the terms of an earlier parole or probation.2 Moreover, should an ex-prisoner subsequently be convicted of another crime, his prior conviction may contribute to increased criminal penalties under an habitual offender statute. ${ }^{3}$ To avoid these consequences he may seek to attack the validity of his conviction and have judgment vacated.

However, the ex-prisoner who attacks the validity of a federal conviction after serving his full sentence under it, may find that all ordinary avenues of redress are closed. ${ }^{4}$ The statutory period for an appeal, ${ }^{5}$ for a motion in arrest of judgment, ${ }^{6}$ or for a new trial ${ }^{7}$ will probably have passed. A motion

1. Former convicts may lose the right to vote or to hold office, and may be ineligible for military service. They may be denied access to professions such as law and medicine, or to licensed occupations limited to persons with certain moral qualifieations. Released prisoners under probationary restrictions may even have additional limitations on their choice of occupations. Ex-convicts who are aliens may be ineligible for naturalization and may be subject to deportation. See Notes, 59 YALE L.J. $786(1950) ; 37$ VA. L. REv. 105 (1951).

2. See Roberts v. United States, 158 F.2d 150 (4th Cir. 1946) (Florida parolee, convicted of federal crime, returned to Florida prison after release from federal penitentiary).

3. See United States v. Morgan, 202 F.2d 67 (2d Cir.), cert. grasifcd, 345 U.S. 974 (1953) ; United States v. Steese, 144 F.2d 439 (3d Cir. 1944).

4. A similar legal problem arises when a petitioner is imprisoned under one federal conviction, but wishes to challenge the validity of another, the sentence under which he has not yet begun to serve. In order to become eligible for parole under the prior conviction, he may have to have the later one vacated. See United States v. Howell, 103 F. Supp. 714 (S.D.W. Va.), aff'd, 199 F.2d 366 (4th Cir. 1952). Section 2255 of the Judicial Code is unavailable since the petitioner is not in custody under the sentence he is attacking. Crow v. United States, 186 F.2d 704 (9th Cir. 1950). Habeas corpus is also unavailable since the petitioner is legally imprisoned under the prior conviction, the validity of which he does not question. McNally v. Hill, 293 U.S. 131 (1934). Therefore, relief must be sought by the writ of error coram nobis.

5. An appeal must be taken within ten days after entry of judgment, or within ten days after entry of an order denying a motion for a new trial or a motion in arrest of judgment. Fen. R. CrRr. P. 37 (a).

6. "The motion in arrest of judgment shall be made within $\mathbf{5}$ days after determination of guilt or within such further time as the court may fix during the $\mathbf{5}$ day pariod." FED. R. CRIMT. P. 34.

7. A motion for a new trial on the basis of newly discovered evidence is limited to 
to correct an illegal sentence ${ }^{8}$ is available only when a sentence is not in conformity with the statute under which pronounced, and prestupposes a valid conviction. ${ }^{9}$ Neither the motion procedure for vacating sentence under Section 2255 of the Judicial Code ${ }^{10}$ nor habeas corpus ${ }^{11}$ is available to one who is not in custody ${ }^{12}$ under the judgment he is attacking. ${ }^{13}$ Consequently, if an ex-prisoner is to secure adequate relief from an invalid federal conviction ${ }^{14}$ he must resort to the writ of error coram nobis.

two years after final judgment. On any other grounds it must be brought within five days after verdict. FED. R. CRIM. P. 33.

8. Fed. R. CRIM. P. 35.

9. In re Shepherd, 195 F.2d 157 (1st Cir. 1952) ; Garrison v. Reeves, 116 F.2d 978 (8th Cir. 1941). But cf. Byrd v. Pescor, 163 F.2d 775 (8th Cir. 1947), cert. dented, 333 U.S. 846 (1948); D'Ostroph v. Pescor, 7 F.R.D. 569 (W.D. Mo. 1947), appeal dismissed, 173 F.2d 897 (8th Cir.), cert. denied, 337 U.S. 926 (1949). In the Byrd casc, supra, the Eighth Circuit denied habeas corpus, holding that Rule 35 gave the petitioner an adequate remedy in the sentencing court to challenge the validity of a conviction. However, in Byrd, the petitioner was in custody under the sentence attacked.

10. 28 U.S.C. $\$ 2255$ (Supp. 1952).

11. 28 U.S.C. $\$ \$ 2241-55$ (Supp. 1952).

12. The Federal Parole Statute states that a parolee is in the legal custody of the Attorney-General. 18 U.S.C. $\$ 4203$ (Supp. 1952). It would seem, therefore, that a parolee could attack a conviction by habeas corpus or section 2255. Sec United States v. Bradford, 194 F.2d 197, 200 (2d Cir.), cert. desied, 343 U.S. 979 (1952). Bul cf. Factor v. Fox, 175 F.2d 626 (6th Cir. 1949) (habeas corpus denied because petitioner not in custody of warden respondent); Weber v. Squire, 315 U.S. 810 (1942), denying cert. to 124 F.2d 618 (9th Cir. 1941) (same); Van Meter v. Sanford, 99 F.2d 511 (5th Cir. 1938) (same).

A probationer is "under supervision." 18 U.S.C. $\$ \S 3653,3655$ (Supp. 1952). But for purposes of habeas corpus and section 2255 he is not "in custody." United States v. Bradford, supra. But see United States v. Kaplan, 101 F. Supp. 7, 11 n.3 (S.D.N.Y. 1951).

13. McNally v. Hill, 293 U.S. 131 (1934) (habeas corpus); United States v. Lavelle, 194 F.2d 202 (2d Cir. 1952) (\$2255); Lopez v. United States, 186 F.2d 707 (9th Cir. 1950) (\$2255); Crow v. United States, 186 F.2d 704 (9th Cir. 1950) (\$ 2255). Contra: Griffin v. United States, 173 F.2d 909, rehearing denicd, 175 F.2d 192 (6th Cir. 1949) ( 2255 ) ; Cf. United States $e x$ rel. Turpin v. Snyder, 183 F.2d 742 (2d Cir. 1950) (habeas corpus).

14. A person who successfully attacks the validity of his conviction subjects himself to the possibility of additional punishment. He can be retried, reconvicted, and resentenced for the same offense. See generally, Whalen, Resentence Without Credit For Time Served: Unequal Protection Of The Lazes, 35 MrNo. L. Rev. 239 (1951); Note, 12 U. of Detroit L.J. 135 (1949). Successful attack on a judgment by either dircct or collateral proceedings is deemed a waiver of immunity from further prosecution on the same charge. Murphy v. Massachusetts, 177 U.S. 155 (1900); Robinson v. United States, 144 F.2d 392 (6th Cir.), aff'd in part, 324 U.S. 282 (1945).

Where there is a reconviction for the same offense, the federal practice is to credit time previously served. Murphy v. Massachusetts, supra; Howell v. United States, 199 F.2d 366 (4th Cir.), affirming 103 F. Supp. 714 (S.D.W. Va. 1952). But cf. McDowell v. State, 225 Ind. 495, 76 N.E.2d 249 (1947). However, such practice is not sanctioned by statute and may depend upon the sentencing court's discretion. For a suggestion that it is possible to have time served under an invalid conviction credited to a valid con- 
Although the law is not settled, ${ }^{15}$ it appears that federal district courts have jurisdiction to entertain coram nobis proceedings. ${ }^{10}$ The purpose of the writ is to vacate judgments obtained without due process of law.17 It is

viction for an entirely different offense, see Griffin v. United States, 173 F.2d 909, 910 (6th Cir. 1949). See also Youst v. United States, 151 F.2d 666 (5th Cir. 1945) (crediting time served under illegal sentences to legal sentences under different counts of the same indictment) ; Ekberg v. United States, 167 F.2d 380 (1st Cir. 1948) (same). Even if time is credited the new sentence may be more severe than the original one. Mfurphy v. Massachusetts, supra; King v. United States, 98 F.2d 291 (D.C. Cir. 193S). Furthermore, eligibility for parole may be deferred because the new sentence runs as of the time it is pronounced and not from the time of the invalid sentence. Debenque $v$. United States, 55 F.2d 202 (D.C. Cir.), cert. denied, 298 U.S. 681 (1936). However, for a suggestion that a prisoner need not serve in toto more than the maximum period of time provided by the statute, see King v. United States, supra at 295 n.3. See also Note, 45 MIICH. L. Rev. 912, 913 (1947).

15. The Supreme Court has declined to decide whether coram nobis is available in federal criminal cases. See United States v. Mayer, 235 U.S. 55, 69 (1914); United States v. Smith, 331 U.S. 469,475 n.4 (1947). The issue has been further complieated by the enactment of section 2255. For discussion of the problems involved, see Donnelly, Unconvicting The Innocent, 6 VAND. L. REv. 20, 24 (1952); Note, 59 YaLE LJJ. 786 (1950).

16. United States v. Morgan, 202 F.2d 67 (2d Cir.), cert. gronited, 345 U.S. 974 (1953) ; Allen v. United States, 162 F.2d 193 (6th Cir. 1947), findings on ren:and aff'd, 170 F.2d 140 (6th Cir. 1948), cert. denied, 338 U.S. \&S0 (1949); Roberts v. United States, 158 F.2d 150 (4th Cir. 1946); Garrison v. United States, 154 F.2d 105 (5th Cir. 1946); United States v. Steese, 144 F.2d 439 (3d Cir. 1944); Robinson v. Johnston, 118 F.2d 998 (9th Cir. 1941), judgment racated and cause rentasded, 316 U.S. 649 (1942), rev'd on other grounds, 130 F.2d 202 (9th Cir. 1942). Conlra: United States v. Kerschman, 201 F.2d 682 (7th Cir. 1953).

17. Garrison v. United States, 154 F.2d 106 (5th Cir. 1946); United States v. Steese, 144 F.2d 439 (3d Cir. 1944). Sec United States v. Mayer, 235 U.S. 55, 69 (1914); Howell v. United States, 172 F.2d 213, 215 (4th Cir.), cert. denied, 337 U.S. 905 (1949); Pierce v. United States, 157 F.2d \$4S (5th Cir. 1946), cert. dexicd, 329 U.S. $\$ 14$ (1947).

At early common law the writ was available in both civil and criminal cases to correct certain errors of fact not appearing in the record and unknown to the defendant, which, had they been known by the court, would have precluded the judgment rendered. See Donnelly, stpra note 15, at 24. It appears that in criminal cases the writ could also be used to correct errors of law. See United States v. Plumer, 27 Fed. Cas. 561, 573, No. 16,056 (C.C.D. Mass. 1859) ; Queen v. O'Connell, 7 Ir. L. R. 261, 357n. (1844). With the growth of the criminal law in the American courts the writ was extended to apply to situations where fraud or duress in the proceedings rendered the judgment a nullity. Sanders v. State, 85 Ind. 318 (18\$2); State v. Calhoun, 50 Kan. 523, 32 Pac. 38 (1893). At the same time, many of the grounds for which coram nobis once had lain were provided for by statutory forms such as the right of appeal and the motion for a new trial. In defining the scope of the writ in United States v. Mlayer, 235 U.S. 55, 69 (1914), Chief Justice Hughes stated that the writ, if available, would lie "where the errors were of the most fundamental character, that is, such as rendered the proceeding itself irregular and invalid." Since that time the scope of coram nobis has been further extended by holdings of the Supreme Court that deprivation of constitutional rights upon trial deprives the court of jurisdiction and renders judgments so obtained invalid. See Fuld, The Writ of Error Coram Nobis, 117 N.Y.L.J. 2212, col. 1, 2230, col. 1, 2248, col. 1 (1947). Holtzoff, Collotcral 
available on such grounds as denial of the right to counsel, ${ }^{18}$ insanity or mental incompetence at the time of the plea or trial, ${ }^{10}$ knowing use of perjured testimony ${ }^{20}$ or suppression of evidence by the prosecution, ${ }^{21}$ fraud or duress in obtaining a plea of guilty, ${ }^{22}$ or mob domination at the trial. ${ }^{23}$ But

Review of Convictions in Federal Courts, 25 B.U.L. Rev. 26 (1945). Thus it appears that the writ, which at one time was used to correct simple errors of fact such as misprisions of the clerk in the record, is now available to challenge the validity of a conviction on jurisdictional or constitutional grounds. See Pierce v. United States, supra at 848; United States v. Steese, supra at 442 (concurring opinion). The principal distinction between coram nobis and section 2255 appears to be that the former is not limited by the "in custody" requirement. Moreover, coram nobis may be available to call to the trial court's attention new facts of such a vital nature as to prove that the decision could not possibly have been correct on its merits. United States v. Monjar, 64 F. Supp. 746 (D. Del. 1946) ; accord, E.v parte Atkinson, 84 F. Supp. 300 (E.D.S.C. 1949) ; Davis v. State, 200 Ind. 88, 161 N.E. 375 (1928). Contra: Kelly v. United States, 138 F.2d 489 (9th Cir. 1943), cert. dented, 324 U.S. 855 (1945) ; Reid v. United States, 149 F.2d 334 (5th Cir. 1945). See also Waldron v. United States, 146 F.2d 145 (6th Cir. 1944) (judgment under an unconstitutional statute vacated) ; United States v. Weil, 46 F. Supp. 323 (E.D. Ark. 1942) (judgment vacated on a matter of law).

It is clear that coram nobis has outgrown its humble origin, but the tyranny of labels persists. The cliche with which the scope of the writ was described centuries ago still returns to plague the courts. Because of the perpetuity of the phrase "errors of fact" some courts have incorrectly analogized the writ to a motion for a new trial with unfortunate consequences to the petitioner. See Bell v. United States, 129 F.2d 290 (5th Cir.), ccrt. denied, 317 U.S. 665 (1942) (request to be present at hearing denied) ; United States v. Lan1dicho, 72 F. Supp. 425 (D. Alaska 1947) (two year period of limitation applied). If analogies must be made on procedural points, they should be predicated upon section 2255 which is substantially similar to the modern writ of coram nobis. See United States v. Hayman, 342 U.S. 205 (1952).

18. United States v. Morgan, 202 F.2d 67 (2d Cir.), cert. granted, 345 U.S. 974 (1953) ; United States v. Steese, 144 F.2d 439 (3d Cir. 1944). Cf. Johnson v. Zerbst, 304 U.S. 458 (1938).

19. Allen v. United States, 162 F.2d 193 (6th Cir. 1947), findings on remand aff'd, 170 F.2d 140 (6th Cir. 1948), cert. denied, 338 U.S. 880 (1949); Roberts v. United States, 158 F.2d 150 (4th Cir. 1946); Robinson v. Johnston, 118 F.2d 998 (9th Cir. 1941), judgment vacated and cause remanded, 316 U.S. 649 (1942), rev'd on other grounds, 130 F.2d 202 (9th Cir. 1942).

20. Garrison v. United States, 154 F.2d 106 (5th Cir. 1946) ; see Tinkoff v. United States, 129 F.2d 21, 22 (7th Cir. 1942) ; cf. Mooney v. Holohan, 294 U.S. 103 (1935).

21. Habeas corpus cases hold that suppression of evidence by the prosecution is a denial of due process, United States $e x \mathrm{rel}$. Montgomery v. Ragen, $86 \mathrm{~F}$. Supp. 382 (N.D. Ill. 1949); see In re Curtis, 36 F. Supp. 408, 410 (D.D.C.), aff'd stib nom. Curtis v. Rives, 123 F.2d 936 (D.C. Cir. 1941). It would appear by analogy that coram nobis is available on that ground in the federal courts. See Howell v. United States, 172 F.2d 213, 215 (4th Cir.), cert. denied, 337 U.S. 906 (1949).

22. United States v. Mahoney, 43 F. Supp. 943 (W.D. La. 1942) (by implication). Cf. Waley v. Johnston, 316 U.S. 101 (1942); Smith v. O'Grady, 312 U.S. 329 (1941).

23. Sanders v. State, 85 Ind. 318 (1882) ; State v. Calhoun, 50 Kan. 523, 32 Pac. 38 (1893). Similarly, federal habeas corpus cases hold that mob domination renders the proceeding invalid. Moore v. Dempsey, 261 U.S. 86 (1923) ; sec Frank v. Mangum, 237 U.S. 309,335 (1915). That habeas corpus and coram nobis are analogous, see note 21 supra. 
the writ's effectiveness has been impaired by a phalanx of court-inposed obstacles.

The foremost impediment to relief is the requirement that the petitioner show not only that he was deprived of due process, but also that he is innocent or has some other valid defense. ${ }^{34}$ This requirement originated in United States $v$. Moore. ${ }^{25}$ There the Seventh Circuit relied on the equity rule that a defendant may not have an invalid judgment vacated unless he shows a meritorious defense so that a retrial will produce a different result." ${ }^{\mathrm{S}}$ The policy of this rule in equity is to prevent useless litigation and secure the finality of civil judgments. ${ }^{2 \pi}$ But in the criminal law, where the necessity of securing due process overrides considerations of finality, the rule is inappropriate. The Moore case also relied on Indiana precedent to support the innocence requirement. 28 In that state, coram nobis is used not only to redress fundamental procedural defects, as in the federal courts, 99 but also to grant relief to those validly convicted who are subsequently able to prove their innocence. ${ }^{30}$ Thus a petitioner there must allege either that he is innocent ${ }^{31}$ or that he was deprived of due process. ${ }^{32}$ Indiana cases require proof

24. United States v. Farnsworth, 198 F.2d 600 (D.C. Cir.), cort. denied, 344 U.S. 915 (1953) ; United States v. Bice, 177 F.2d 843 (4th Cir.), affirming \&4 F. Supp. 290 (D. Md. 1949) ; United States v. Rockower, 171 F.2d 423 (2d Cir. 1943), cert. denisd, 337 C.S. 931 (1949) ; United States v. MLore, 166 F.2d 102 (7th Cir.), ccrt. denicd, 334 U.S. 849 (1948). Contra: United States v. Morgan, 202 F.2d 67 (2d Cir.), corl. yranted, 345 C..S. 974 (1933); Garrison v. United States, 154 F.2d 106 (5th Cir. 1946); United States v. Steese, 144 F.2d 439 (3d Cir. 1944).

25. 166 F.2d 102 (7th Cir.), cert. dcnicd, $33+$ U.S. $\$ 49$ (1948).

26. For the equity rule, see Glinski v. United States, 93 F.2d 418 (7th Cir. 1937) ; Mrass. Benefit Life Ins. v. Lohmiller, 74 Fed. 23 (7th Cir. 1896) ; Emcee Carp. v. George, 393 III. App. 240, 12 N.E.2d 333 (1937) ; Fitzgerald v. Power, 225 Ill. App. 118 (1922); Braun v. Quinn, 112 Neb. 485, 199 N.W. \&2S (1924). The cases supra are cited in United States v. IIoore, 166 F.2d 102, 104 (7th Cir.), cert. dinied, 334 U.S. 849 (1948).

27. See cases cited note 26 sitpra.

28. See United States v. Moore, 166 F.2d 102, 104 (7th Cir.), cort. deried, 334 U.S. 849 (1948), and cases therein cited.

29. See note 17 supra.

30. "The rule is that the extraordinary relief afforded by a proceeding in the nature of a writ of coram nobis will not be granted in a criminal case after trial and conviction, except where it clearly appears that the petitioner had a valid defense in the facts of the case, but which, without negligence on his part, was not made because of duress, fraud, or excusable mistake; or that he was prevented from asserting and enjoying some legal right through duress, or fraud, or excusable mistake, these facts not appearing on the face of the record, and being such as, if known in season, would have prevented the rendition and entry of the judgment in question." Wheeler v. State, 158 Ind. 687, 696, 63 N.E. 975, 978 (1902) (emphasis supplied). See Note, Habeas Corpus and Coram Nobis in Indiana, 26 Ino. L.J. 529 (1951).

31. Davis v. State, 200 Ind. \&S, 161 N.E. 375 (1928), crorruled in fart, Stephenson v. State, 205 Ind. 141, 196-7, 179 N.E. 633, 186 N.E. 293, 295 (1933) ; see George v. State, 211 Ind. $429,439,6$ N.E. 2 d 336,340 (1937).

32. Dearing v. State, 229 Ind. 131, 95 N.E.2d 832 (1951); Sanders v. State, 85 Ind. 318 (1888). 
of innocence when that is the petitioner's ground for relief. ${ }^{33}$ Moore nisinterpreted these decisions in holding that both elements of proof were necessary to support federal coram nobis. ${ }^{34}$

The rationale for applying the innocence requirement to coram nobis is that unless a retrial would result in a different verdict it would be vain and idle to set aside the judgment. ${ }^{35}$ But a defendant is entitled to his day in court protected by all the constitutional safeguards guaranteed the accused. If he has never been validly adjudged guilty, to require him to prove his innocence before a court is to shift the burden of proof ${ }^{36}$ and deprive him of a valid trial by jury. Until such a trial is had an accused should be considered innocent. ${ }^{37}$ The only issue which is relevant and which the petitioner should have to prove is that he was deprived of due process. ${ }^{38}$

33. Shipley v. State, 210 Ind. 253, 2 N.E.2d 389 (1936) ; cases cited note 31 supra.

34. Moore relies heavily on Shipley v. State, supra note 33. While Moorc was seeking coram nobis on the ground that he had been deprived of due process, Shipley alleged that he was innocent. The Shipley case decided merely that the allegations, even if true, would not establish Shipley's innocence.

In United States v. Monjar, 64 F. Supp. 746 (D. Del. 1946), a federal coram nobis hear* ing was granted on grounds of innocence. Accord, Ex partc Atkinson, 84 F. Supp. 300 (E.D.S.C. 1949). Contra; Reid v. United States, 149 F.2d 334 (5th Cir. 1945); Kelly v. United States, 138 F.2d 489 (9th Cir. 1944), cert. denicd, 324 U.S. 855 (1945).

35. See United States v. Moore, 166 F.2d 102, 104 (7th Cir.), ccrt. denied, 334 U.S. 849 (1948).

36. State v. Calhoun, 50 Kan. 523, 32 Pac. 38 (1893). "And further, held, that the question of the guilt or innocence of the accused in such a case is not a necessary question to be determined in the case; that a mob cannot, by compelling a person accused of crime to plead guilty and to be sentenced to imprisonment and hard labor in the penitentiary, so shift the burden of proof from the state to the accused as to compel the accused to prove his innocence, and to prove it by a preponderance of the testimony, and to relieve the state from proving his guilt, and from proving it by evidence sufficient to remove every reasonable doubt." Id. at 538-9, 32 Pac. at 42.

It would seem that the duty of the Government to establish proof of guilt is a requircment of due process within the scope of the Fifth Amendment. See Leland v. Oregon, 343 U.S. 790, 802-03 (1951) (dissenting opinion). See also Tot v. United States, 319 U.S. 463, 469 (1943).

37. If the defendant shows that he has been deprived of due process, the judgment should be vacated and the criminal proceeding returned to the indictment stage. The government may then proceed in its attempt to prove the defendant guilty. State v. Calhoun, 50 Kan. 523, 32 Pac. 38 (1893); Sanders v. State, 85 Ind. 318 (1882).

38. "It should be patent from the foregoing that it is not the function of this Court to concern itself, in a proceeding of this nature, with the guilt or innocence of the petitioner. A guilty person, in custody pursuant to a void judgment, is just as improperly deprived of his liberty as is an innocent person." Allen v. United States, 102 F. Supp. 866, 869 (N.D. IIl. 1952) (motion to vacate judgment under section 2255).

The innocence requirement has been applied to section 2255 in cases relying on the authority of United States v. Moore, 166 F.2d 102 (7th Cir.), cert. denicd, 334 U.S. 849 (1948). This requirement seriously threatens to impair that section which is substantially the modern equivalent for habeas corpus as the means of attacking invalid federal convic- 
Another equity rule ${ }^{39}$ which has been transposed into the law of coram nobis is the doctrine of laches. ${ }^{40}$ First appearing in federal cases as dicta ${ }^{21}$ it now threatens to destroy the efficacy of the writ. An ex-prisoner who first learns of his rights after release from custody will have little immediate reason to attack his conviction. ${ }^{22}$ Yet, if he does not attack it until he suffers some additional penalty, ${ }^{43}$ he may be barred from relief by his delay. ${ }^{44}$ The argument for application of the laches doctrine is based on considerations of finality: witnesses die or their memories grow dim, and law enforcement officers will be handicapped if they must re-prosecute. ${ }^{20}$ But delay works

tions when one is in custody. United States v. Mlorris, 83 F. Supp. 970 (D.D.C. 1949); accord, United States v. Paglia, 190 F.2d 445 (2d Cir. 1951). Sce United States v. Bremer, 9th Cir., Sept. 30, 1953; Ziebart v. United States, 192 F.2d S04, S05 (5th Cir. 1951) ; United States v. Bowen, 94 F. Supp. 1006, 1009 (N.D. Ga.), aff'd, 192 F.2d 515, 516 (5th Cir. 1951), cert. denied, 343 U.S. 943 (1952) ; United States v. Calp, $\$ 3$ F. Supp. 152, 155 (D. Md. 1949). Contra: Allen v. United States, supra.

39. See Mass. Benefit Life Ins. Co. v. Lohmiller, 74 Fed. 23 (7th Cir. 1896); Thorge v. Wm. Filene's Sons Co., 40 F.2d 269 (D. MIass. 1930).

40. See Farnsworth v. United States, 198 F.2d 600 (D.C. Cir.), cert. dericd, 344 U.S. 915 (1953) ; United States v. Bice, 177 F.2d S43 (4th Cir.), affirming S4 F. Supp. 290 (D. Md. 1949) ; United States v. Rockower, 171 F.2d 423 (2d Cir. 194\$), cort. dcrisd, 337 U.S. 931 (1949); United States v. Moore, 166 F.2d 102 (7th Cir.), cert. deriicd, 334 U.S. 849 (1948).

41. See Spaulding v. United States, 155 F.2d 919, 921 (6th Cir. 1946); United States v. Wright, 56 F. Supp. 489, 492 (E.D. Ill. 1944) ; United States v. Buhler, 48 F. Supp. 159, 160 (M.D. Pa. 1942); United States v. Mahoney, 43 F. Supp. 943, 945 (W.D. La. 1942).

42. However, an illegally convicted ex-convict may desire to have the judgment vaeated by coram nobis proceedings so that he might then petition the sentencing court for a certificate of innocence, and thus become eligible to bring an action in the United States Court of Claims for indemnification under the Federal Erroneous Convictions Act, 2S U.S.C. $\$ 2513$ (Supp. 1952). See United States v. Keegan, 71 F. Supp. 623 (S.D.N.Y. 1947) ; Donnelly, Unconvicting The Innocent, 6 VANp. L.J. 20, 33 (1952).

43. See notes 1-3 sispra and accompanying text.

44. Farnsworth v. United States, 198 F.2d 600 (D.C. Cir.), cort. denicd, 344 U.S. 915 (1953) (alternate holding-17 years after conviction); United States v. Bice, 177 F.2d 843 (4th Cir.), affirming 84 F. Supp. 290 (D. Md. 1949) (alternate holding-23 years after conviction) ; United States v. Rockower, 171 F.2d 423 (2d Cir. 1948), cert. deriscd, 337 U.S. 931 (1949) (alternate holding-18 years after conviction) ; United States v. Afoore, 166 F.2d 102 (7th Cir.), cert. denied, 334 U.S. $\$ 49$ (1948) (alternate holding-18 years after conviction). Contra: United States v. Morgan, 202 F.2d 67 (2d Cir.), cert. granted, 345 U.S. 974 (1953) (13 years after conviction); United States v. Steese, 144 F.2d 439 (3d Cir. 1944) ( 9 years after conviction).

It is not clear in what manner the doctrine of laches is applied. In some eases it appears that relief is completely barred by the lapse of an arbitrary number of years after conviction. See United States v. Bice, supra; Farnsworth v. United States, sufro. Other cases seem to indicate that a presumption of laches arises after an unspecificd time, and that the petitioner has the burden of negating the presumption by showing diligence in asserting his rights. See United States v. Moore, supra; United States v. Rockower, sispro.

45. See United States v. Moore, supra note 44, at 105; Irwin v. State, 220 Ind. 223, 246, 41 N.E.2d S09, 815-16 (1942) ("All limitation upon the assertion of rights or the 
equally to the disadvantage of the petitioner who has the burden of proving the judgment void.4 And the inconvenience to the prosecution is minimal when compared to the injustice suffered by the illegally convicted petitioner. ${ }^{47}$ An unfair trial should not become unassailable through mere passage of time or because of a petitioner's failure to ascertain or assert his rights. ${ }^{48}$ Laches should be used to prevent not perpetuate inequity.

A convict in state custody under an habitual offender sentence predicated upon a prior federal conviction may encounter a further obstacle to coram nobis if he attacks the validity of that conviction. Even if he is not barred from relief because of laches or the proof of innocence requirement, he may be denied redress because of misapplication of the rule in Gayes $v$. Now York.49 In that case, the Supreme Court held that where a state gave a convict an opportunity when sentencing him as a second offender to question the validity of a prior state conviction, later refusal by the state to permit collateral attack on the first conviction did not violate due process of law. By a process of legal alchemy that decision has been interpreted to mean that opportunity to attack a prior federal conviction is available in a state court at the time of habitual offender sentencing, and that federal relief at a later time is therefore precluded. ${ }^{50}$ Even if such opportunity were available in the state court, ${ }^{61}$ nothing in the Gayes case requires that fecleral relief be precluded thereafter. Gayes holds that a state's failure to provide later relief does not violate the

granting of remedies is based upon sound public policy, the reasons for which necd no elaboration. ... These limitations operate upon just and unjust claims alike. It has been thought necessary to deny the right to the assertion of even just claims in order that there may be finality and repose. It has not been supposed that the machinery of human justice can operate with perfection and exactness.") This reasoning has becu overruled in State v. Lindsey,-Ind.--, 106 N.E.2d 230 (1952).

46. United States v. Morgan, 202 F.2d 67 (2d Cir.), cert. granted, 345 U.S. 974 (1953); cf. Allen v. United States, 102 F. Supp. 866 (N.D. Ill. 1952) (hearing under section 2255).

47. See Desmond J., in People v. Richetti, 302 N.Y. 290, 295, 97 N.E. 2d 908, 910 (1951) : "The possibility, or probability, that such trials will be numerous, is no answer at all, and will not be further noticed herein. Likewise, as to the fact that defendant is a convict, and the opposing affiants court officers. Defendant has been denied his day in court, and we must see that he has it, be he right or wrong, truthful or lying, good citizen or bad."

48. "As to the Government's remaining contention, i.c., that Allen did not assert his constitutional right with due diligence and, therefore, is not entitled to relief, the Court is unable to perceive its applicability. A void judgment is as void today as it was twenty years ago. No aging process, whereby a void judgment improves as to stature and validity by the passage of time, can properly be interposed." Allen v. United States, 102 F. Supp. 866, 869 (N.D. Ill. 1952) (motion to vacate judgment under section 2255).

49. 332 U.S. 145 (1947).

50. Farnsworth v. United States, 198 F.2d 600 (D.C. Cir.), cert. denicd, 344 U.S. 915 (1953) ; United States v. Bice, 177 F.2d 843 (4th Cir.), affirming 84 F. Supp. 290 (D. Md. 1949); United States v. Rockower, 171 F.2d 423 (2d Cir. 1948), cert. denied, 337 U.S. 931 (1949); United States v. Moore, 166 F.2d 102 (7th Cir.), cert. denied, 334 U.S. 849 (1948). Contra: United States v. Morgan, 202 F.2d 67 (2d Cir.), cert. granted, 345 U.S. 974 (1953).

51. But see note 54 infra. 
Fourteenth Amendment.52 It does not suggest such a practice for the federal courts. $^{53}$

Furthermore, it appears that opportunity to attack a prior federal conviction is not available in state courts. The New York Court of Appeals has held that until a federal conviction is vacated in the federal courts, it will serve as an effective predicate for sentencing under the New York Habitual Offender statute. ${ }^{54}$ The procedure which the courts should follow is to require the petitioner first to attack his federal conviction in the federal district court where he was sentenced, and if successful, then to apply to the state courts for resentencing as a first offender. ${ }^{55}$ The primary obligation to remove the consequences of an invalid judgment should be on the court which rendered it.

In the recent case of United States $v$. Morgan ${ }^{50}$ the Second Circuit conspicuously omitted reference to the obstacles previously imposed on coram nobis relief. Miorgan had been sentenced by a New York court as a second offender on the basis of a prior federal conviction. When opportunity to attack that conviction was denied him by the New York courts, he applied for coram nobis in the federal courts. Morgan's petition apparently failed to allege his innocence and also failed to assert his freedom from laches although it was filed thirteen years after his federal conviction, nine years after release from federal imprisonment, and two years after sentencing in New York. The Second Circuit recognized that the federal courts are the proper forum for attacking an invalid federal conviction. Moreover, the court apparently overruled sub silentio a previous decision requiring proof of innocence and freedom from laches, ${ }^{57}$ by overlooking the omission of these

52. 332 U.S. 145, 148-9 (1947). The New York Court of Appeals, correctly interpreting the Gayes case, has distinguished it on Fourteenth Amendment grounds. Bojinoff v. People, 299 N.Y. 145, 85 N.E.2d 909 (1949) (failure to attack a prior New York conviction at time of sentence as a second offender not a bar to coram nobis proceedings at a later date), 16 BROOKLYN L. Rev. 124 (1949).

53. Four justices dissented in Gayes on the ground that the state procedure, as interpreted, violated the Fourteenth Amendment. "I am unwilling to subscribe to such a doctrine of forfeitures concerning constitutional rights, which in the extreme circumstances of this case seems to me shocking." Justice Rutledge, with whom Justices Blacl; Douglas, and Murphy concurred, 332 U.S. 145, 151 (1947) (dissenting opinion). Because of the higher standards of criminal procedure required under the Fifth Amendment, it is possible that if federal procedure had been involved the result would have been different.

54. People v. McCullough, 300 N.Y. 107, $\$ 9$ N.E.2d 335 (1949), cert. dcricd, 339 U.S. 924 (1950).

55. See United States ex rol. Lavelle v. Fay, 205 F.2d 294 (2d Cir. 1953); United States v. Morgan, 202 F.2d 67 (2d Cir.), cert. granted, 345 U.S. 974 (1953) ; People v. McCullough, 300 N.Y. 107, 89 N.E.2d 335 (1949), cert. denicd, 339 U.S. 924 (1950).

56. 202 F.2d 67 (2d Cir.), cert. granted, 345 U.S. 974 (1953), 66 HAsw. L. REv. 1137, 53 COL L. Rev. 737.

57. United States v. Rockower, 171 F.2d 423 (2d Cir. 1948), cert. dericd, 337 U.S. 931 (1949). 
allegations in the petition. The opinion indicates that the only requisite to relief is a showing that the petitioner had been cleprived of due process. High standards of criminal procedure require that an effective means of obtaining relief from invalid convictions be available so long as their consequences are felt. Supreme Court affirmance of Morgan will provide such a remedy by paving the way for a more available and effective writ of error coram nobis.

58. United States v. Morgan, 202 F.2d 67, 68-9 (2d Cir.), cert. granted, 345 U.S. 974 (1953). See also Allen v. United States, 102 F. Supp. 866 (N.D. Ill. 1952). 